\title{
DIGITAL TRANSFORMATION OF VOCATIONAL EDUCATIONAL ORGANIZATIONS OF UKRAINE: EUROPEAN VECTOR
}

\section{Olena Kulynych}

The article presents an overview of normative documents, research results, conclusions on the topic of digital transformation of education systems, in particular in the EU countries. The generalization of materials, which help to define, at what stage of digital transformations there is an education of Ukraine, a place of system of vocational education in this global process, is presented. Examples are given as an active position in the direction of ensuring digital transformations of educational and managerial processes in a particular educational institution; it contributes to the implementation of national tasks in the direction of ensuring the digital development of society. Emphasis is placed on how the role of methodological services is changing, on the need for systemic changes in the perception of the educational institution's perception of the process of ensuring the digital development of both teachers and students, and vocational education institutions in general. The study examines four vectors of digital development for vocational (technical) education institutions of Ukraine from the possible options, proposed by European colleagues who have already shown positive results at the level of the education system (vocational in particular) and a separate institution of vocational (technical) education. In particular, the possibility of measuring the level of digital development of the educational institution through the use of the SELFIE service, developed by the European Commission together with a group of educational experts and practitioners from European countries, was considered. The platform is available in more than thirty languages, including Ukrainian. Examples of online tools common in both European educational communities and those, developed by domestic specialists (but taking into account European experience,) are given, thanks to which it is possible to carry out self-assessment, assessment, and soon certification of digital competencies of teachers. Ways to solve the problem of insufficient digital literacy of students, which, along with Ukrainian, and European researchers pay attention to, are given. There are wide opportunities for the development of digital infrastructure, which provides educational institutions with participation in competitions and programs of the European Union, such as Erasmus + Keywords: digital transformation of education, digital competencies, European experience, vocational education institution, methodical service

(C) The Author(s) 2021

This is an open access article under the Creative Commons CC BY license

How to cite:

Kulynych, O. (2021). Digital transformation of vocational educational organizations of ukraine: european vector. ScienceRise: Pedagogical Education, 4 (43), 12-17. doi: http://doi.org/10.15587/2519-4984.2021.238001

\section{Introduction}

The digital transformation of education and the topic of digital competencies are gaining more and more powerful features in the policy and actions of the European Union, and thus in Ukraine, whose further development we see in close cooperation, common aspirations with the EU, with the world progressive community.

Of course, it was the consequences of Covid-19 that accelerated these processes, had a profound impact on people's lives and businesses, and options for adapting to the new reality. Satya Nadella, CEO of Microsoft, described the impact of Covid-19 on technology implementation and improvement as follows: "In two months, we have seen a digital transformation for two years." Independent research by McKinsey and KPMG has shown that at least $80-85 \%$ of global business leaders believe that the pandemic has accelerated digital transformation, and $30 \%$ admit that the process of digitizing operational activities has not just accelerated, but carried them forward in time.
Already today, business representatives are acutely aware of the lack of staff training in digital skills. Approximately $35 \%$ of McKinsey respondents said they would need more workers skilled in automation, artificial intelligence and robotics [1]. Between 77 and $88 \%$ of respondents in Ukraine and around the world say they will continue to develop the tools of digital cooperation and communication, introduced as a result of the pandemic [2].

Thus, digital competence becomes part of the core set of competencies for the workforce in the new environment. Therefore, it should become an integral part of the curriculum, a component and format of the learning environments of vocational education institutions.

In addition to providing young people with the appropriate set of competencies, a vocational education institution can play a key role in providing ongoing adult learning, career support and employment. Therefore, steps are needed in the direction of digital development of vocational education institutions, ensuring 
the level of digital competence of graduates, not lower than the basic one.

\section{Literary review}

Consider some European strategic decisions to ensure digital transformation, development of digital competencies, which will develop a national strategy for digital transformation, provide digital development and vocational education in Ukraine.

Among the priorities of the European Commission for 2019-2024, we will mention the direction "Europe fit for the digital age" which is implemented through the "European Digital Strategy" As part of the implementation of these conceptual principles, on March 9, 2021, the Commission presented the "Digital Compass" - a vision and ways of digital transformation of Europe by 2030 "2030 Digital Compass: the European way for the Digital Decade" [3].

As part of the development of the European Educational Area, on 18 February 2021 the EU Council adopted a "Council Resolution on a strategic framework for European cooperation in education and training towards the European Education Area and beyond (20212030)", among the strategic priorities of which is the digital transition (digital transformation, ed.) [4].

The need to digitize vocational education as a driving force for innovative transformation, a factor in increasing the attractiveness of vocational education is discussed in the Council of Europe Recommendations of 24 November 2020 on vocational education and training (VET) for sustainable competitiveness, social justice and sustainability [5].

The recently published report "Innovation and Digitization: Report of the ET2020 Working Group on Vocational Education and Training" presents 1 vision, 2 perspectives and 8 views, as well as best practices from across Europe to show how innovation and digitization contribute quality vocational education in the new conditions, offer ways to overcome the insufficient level of digital literacy of participants in educational systems [6].

«Council conclusions on digital education in Europe's knowledge societies», published on December 1, 2020 [7], call for the introduction of digital educational technologies and the acquisition of digital competences in order to improve teaching, learning at all levels of education and lifelong learning.

On December 10, 2020, the Third European Summit on Education was held, which considered the Commission's vision for the creation of a European educational space by 2025 [8] and agreed on the intention to implement the Digital Education Action Plan 2021-2027, Resetting education and training for the digital age [9].

Non-governmental organizations, such as the panEuropean community "ALL DIGITAL", are also involved in the process of digital transformation and development of digital competencies. On May 6, 2021, the organization presented a new version of the Digital Manifesto, which aims to support dialogue and cooperation to ensure the digital future of Europe [10].

Ukraine is at a critical stage of digital transformation. The resolution of the Cabinet of Ministers of January 30, 2019 No. 56 "Some issues of digital development" (as amended), approved the principles of im- plementation of the principles of state policy of digital development by executive authorities. The order of the Cabinet of Ministers of Ukraine of March 3, 2021 No. 167-r approved the Concept of development of digital competencies, the implementation of which will accelerate the process of digital transformation in Ukraine. It should be noted, that national strategies for the development of digital competences and digital transformation in the EU countries are considered to be top-level policy documents that set the main objectives for the development of digital skills and competences, determine the necessary resources for their implementation. The European Commission recommends that all EU Member States and neighboring countries adopt national strategies to develop digital skills and competences. The analytical document "Guide to the development of the National Strategy for the Development of Digital Skills and Competences in Ukraine in accordance with European experience", presented on April 27, 2021, summarizes the European experience in developing strategies on European best practices and contains a set of steps and recommendations for developing and implementing the National Strategy of development of digital skills and competencies in Ukraine [11].

\section{Research aim and tasks}

The aim of the study is to analyze the strategic steps, already taken in the EU towards digital transformation, the experience of European colleagues in the development of digital competencies, to determine their impact on the development of digital systemic transformations in Ukraine in general and in education in particular, identify vectors of digital development, already shown the positive dynamics in European education systems, to test their effectiveness and impact on the ability to provide digital transformation of educational and management processes within a particular vocational education institution.

To achieve this goal, the following tasks were set:

1. To review normative documents, research results, conclusions on the topic of digital transformation of education systems, in particular vocational education in the EU, the experience of European colleagues in the development of digital competencies.

2. To summarize the materials that help determine at what stage of digital transformation is the education of Ukraine, the place of the vocational education system in this global process.

3. To identify individual vectors of digital development for vocational (technical) education institutions of Ukraine from possible options, proposed by European colleagues who have already shown positive results both at the level of the education system as a whole, and individual vocational (technical) education institutions.

4. In the course of experimental activities within a specific institution of vocational (technical) education, to test the impact of active movement in these areas on the ability to provide digital transformations of educational and management processes.

\section{Materials and methods}

In the course of acquaintance with materials on the topic of digital transformation of education systems, 
in particular vocational education in EU countries, determining the impact of this global process on the education system of Ukraine, the method of empirical analysis and synthesis was applied that allowed to get a general idea of the phenomenon, to identify groups of tools, areas, movements that ensure the positive dynamics of digital development of educational systems and institutions. Drawing an analogy between the progressive experience of system development of digital transformation, development of digital competencies in the EU and the steps, already taken in Ukraine, allowed to identify both problematic points (lack of systemic vision of digital transformation) and identify the positive dynamics in the direction of ensuring digital development of the domestic educational sector, each educational institution. With the help of abstraction (specifically - identification), four vectors of the movement for setting and planning experimental activities for digital transformation of a particular institution of vocational (technical) education are identified, a step is taken towards forming a model of this process based on the experience of European researchers, its key components are determined.

\section{Research results}

Vocational education in Ukraine, as well as the educational system as a whole, does not yet have a systematic vision of digital transformation, a program document that would ensure the digital transformation and development of each educational institution. But the positive dynamics in this direction is clearly visible. The concept of digital transformation of education and science for the period up to 2026, recently presented by the Ministry of Education and Science of Ukraine, represents a comprehensive strategic vision of the digital transformation of education and science.

The task of each educational institution, in particular vocational, at this stage is an active position in the direction of ensuring the digital transformation of educational and management processes; building new formats of communication with communities, relations with employers; ensuring the development of digital competencies of teachers, students. This study is devoted to finding ways to build a policy of digital development of vocational education institutions, based on the experience of European educational systems.

The published draft of the Concept of Digital Transformation of Education and Science for the period up to 2026 states: "Today's education and science system must undergo radical digital changes and meet global trends in digital development for each person to successfully realize their potential. Today, more and more professions need to acquire a high level of digital skills and mastery of new technologies. This need is also exacerbated by the effects of the COVID-19 coronavirus pandemic, which has exacerbated the problem of developing and mastering technology in the education system to ensure citizens' rights to quality education. Acquisition of digital competencies is becoming a basic need for everyone, so the Ukrainian education system should ensure the formation of digital competencies of students, lecturers and research and teaching staff and the development of digital infrastructure and electronic services in educational institutions in general" [12]
Based on the analysis of information sources of both European and domestic origin, four main vectors of digital development for vocational (technical) education institutions were identified. These areas, defined in European documents and taken into account in domestic counterparts, have already shown positive results both at the level of the education system (vocational in particular) and a separate institution of vocational (technical) education.

The first direction. Measuring the actual level of digital readiness (digital development) of an educational institution.

On April 20, 2021, the European Education Foundation in partnership with the Joint Research Center of the European Commission, in close cooperation with the Ministry of Education and Science and the Ministry of Digital Transformation of Ukraine launched a pilot project SELFIE (self-reflection on effective learning by promoting free innovative educational technologies), a modern tool, designed to help educational institutions implement digital technologies in the educational process. In total, 90 educational institutions took part in the project, of which 30 are $\mathrm{V}(\mathrm{T}) \mathrm{C}$ institutions from 10 regions of Ukraine. Almost 20,000 participants took part in the pilot project. Presentation of the preliminary results of the pilot implementation of SELFIE in educational institutions of Ukraine took place in the format of Hackathon [13].

From January 25 to February 14, 2021, the staff and students of the state educational institution "Zaporizhzhya Higher Vocational School" (hereinafter Zaporizhzhya HVS) were interviewed SELFIE, and almost the first in Ukraine had the opportunity to see the effectiveness and results of this tool. As a result of the survey, an interactive report-snapshot was received, on the basis of which it was actually recommended to develop a plan for digital development of the institution. In addition, the award of the survey participant was formed (Fig. 1).

It should be noted, that after the publication of the Guidelines for the formation of the internal system of quality assurance in vocational education institutions in May 2021, the administration and methodological services of each institution develop or amend the relevant Regulations. According to the author, regular use of the SELFIE survey can and should be part of the internal quality assurance system of vocational education (technical) education.

The second direction. Determining the level of digital competence of teachers and restructuring the methodological system of vocational education.

Recently, the Ukrainian analogue of the European Digital Competence Framework (DigComp) "Description of the Digital Competence Framework for Citizens of Ukraine" [14] was presented for public discussion, and the project "Description of Digital Competence of Pedagogical workers" (analog of the European Digital Competence Framework for Teachers DigCompEdu) was developed.

The Ministry of Education and Science, together with the Digital Ministry, has launched a separate version of the digital chart for teachers, which will help teachers to objectively assess their own level of digital 
competence. Already today methodical services, after interrogation of pedagogical workers by means of the specified digital diagram for teachers, receive the basic information for a structure of individual and group work in the direction of development of digital competence of pedagogical workers.

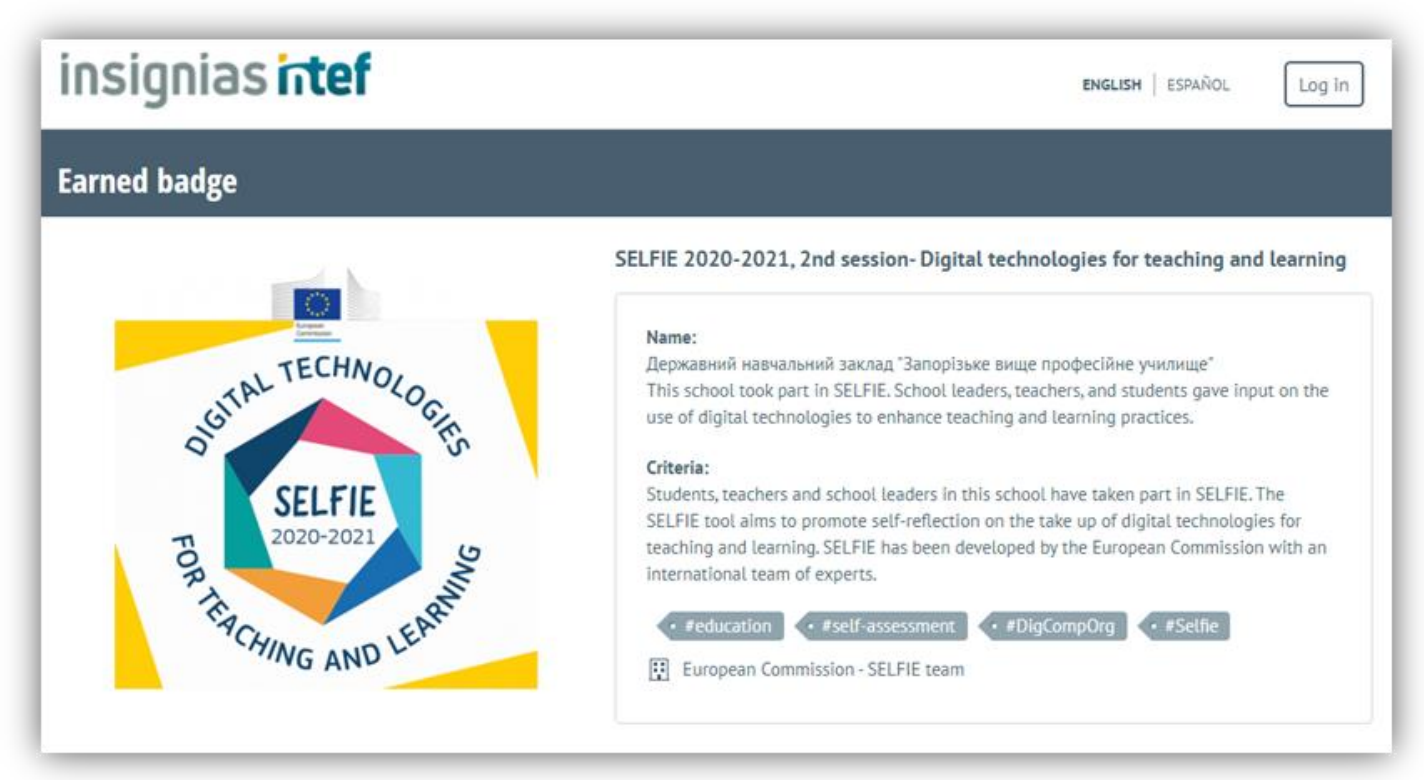

Fig. 1. diploma of the participant of the SELFIE survey of the state educational institution "Zaporizhzhya Higher Vocational School"

In order to determine the level of digital competence of the pedagogical staff, the methodical service of Zaporizhzhya HVS, in addition to digitgrams, also uses European self-assessment services for the level of digital competence. For example, the Englishlanguage service THE DIGITAL COMPETENCE WHEEL [15] or MyDigiSkills [16]. Note that the selfassessment service MyDigiSkills allows you to assess the level of digital competence in five areas of the European digital competence system for citizens DigComp and has a Ukrainian version.

Recently, the Ukrainian Association of Information Technology Specialists and the Ministry of Finance signed a memorandum, according to which Ukraine will introduce the International Computer Driver License (ICDL). ICDL is a certification that allows you to certify your computer skills according to international standards. The program plans to create a digital learning system with 22 training modules, which cover all the necessary digital competencies, in accordance with the European vision, an agreement has been reached to promote the development of digital competencies, including teachers.

Thus, the methodological services of vocational education institutions today should refocus on the use of opportunities, provided by digital technologies, to ensure the systematic development of digital competencies of teachers, using both domestic and European services for self-assessment, assessment and certification of digital competencies.

Here is an example of reorientation of the format of methodological activities. Thus, in the Zaporizhzhya HVS school in the 2020/2021 academic year, instead of an exhibition of printed methodological developments of teachers, a "Competition Review of the best distance learning course" was organized and held, for which a corresponding provision was developed [17].

Methodological services should look for and suggest ways to reduce the burden on the teacher in the context of digitalization of education. It should be noted that, unfortunately, the system of maintaining traditional training and planning documentation, the obligation to use and generate digital content is imposed as an additional burden that is not regulated or paid. For example, in Zaporizhzhya HVS there was an attempt to introduce electronic journals, in particular, registration was carried out on the Atoms platform [18].

However, in the context of mandatory duplication of information in paper journals, which is regulated by outdated instructions, this has become an unjustified additional burden and forced for a period of mixed / remote format of cooperation during quarantine restrictions to find a compromise to publish schedules and direct references to tasks for students. Such a digital resource was the blog "Remote platform of ZHVS" [19]. Note that links to tasks on open platforms should be provided using corporate accounts, such as the Google Workspace for Education platform (formerly G Suite for education).

The third direction. Among the priority areas of the plan for digital transformation of an educational institution should be not only the development of digital competence of teachers, but also systematic steps towards ensuring the appropriate level of digital competence of graduates.

According to the results of the SELFIE survey, conducted at Zaporizhzhya HVS, among the factors, hindering the use of digital technologies, teachers rated the factor "lack of time for teachers" and "low digital competence of students" the same - as $54.5 \%$ (Fig. 2) 
Factors, hindering the use of digital technologies

What factors negatively influence the learning process with using digital technologies at your educational institution?

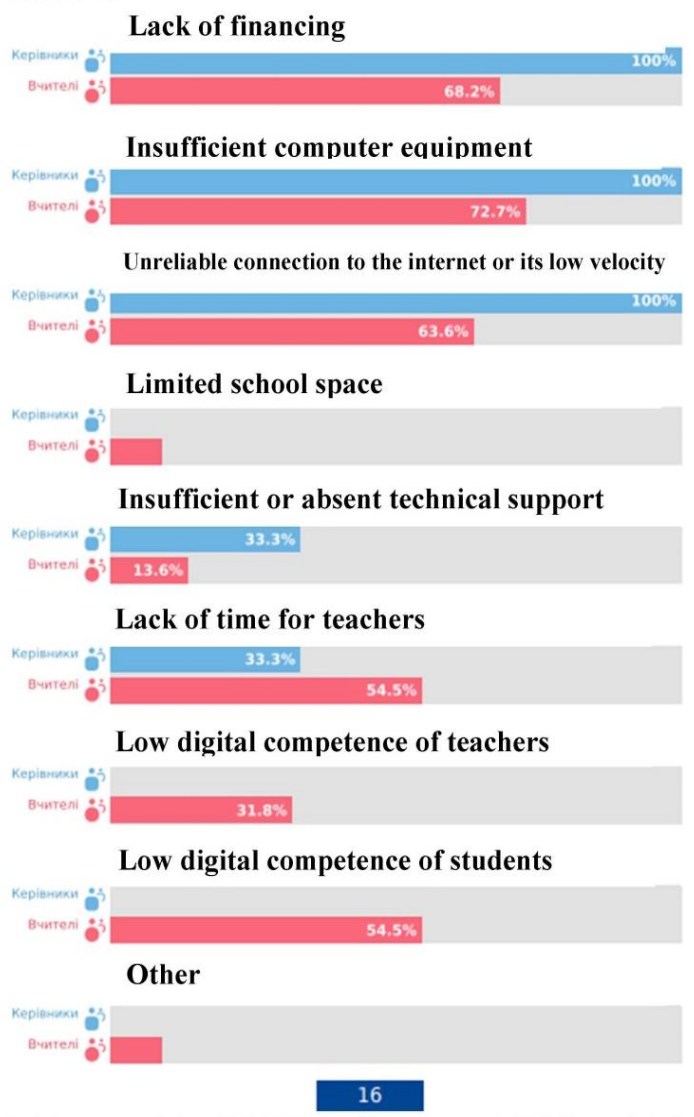

Fig. 2. Element of the SELFIE survey report of SEI Zaporizhzhya HVS

This means that elements of digital competence development must be introduced into the training program for skilled workers today. When creating educational programs, it is necessary to either review and expand the content of the subject "Information Technology", or to introduce a new subject at the expense of the subjects of the sample cycle, such as "Digital Literacy", which allows to master such categories as information security, cloud services and acquaintance with possibilities of the state digital services (Diya), etc.

The fourth direction. A systematic approach to the development of digital infrastructure. This is the most painful area in terms of underfunding of vocational (technical) education. To solve the problems in this area, vocational (technical) education institutions must reach a completely new level of relations with employers and stakeholders, take an active position in the structure of public-private partnership, master fundraising techniques, in particular participate in European Union competitions, Erasmus + and so on.

In the conducted experiment, based on the experience of digital transformation of European educational systems, the key components to be studied were reserves of the educational institution, mainly limited by a look at the internal ones. The study did not consider the impact of external factors, which include the following: cooperation with higher education institutions, employers, stakeholders in the direction of digitization of educational programs, the use of $\mathrm{AI}, \mathrm{VR}, \mathrm{AR}$ in training skilled workers, the impact of such a phenomenon as the Fourth industrial revolution, Industry 4.0 technology, and now 5.0. Particular attention, in further research, should be paid to the impact of such phenomena as "digital inequality" and "digital divide" on the quality of digital transformations of educational systems by overcoming the negative impact of these phenomena.

Decisions to determine the areas, in which to make digital transformations in vocational education institutions, were formed under the influence of analysis of documents on relevant topics, which are publicly available, so the author does not claim to exhaustive list of existing database of normative and literary sources. Experience can and should be complemented by other sources of information, transformed under the influence of new research in the direction of digital transformation of education and the economy as a whole.

\section{Conclusions}

1. The study analyzed normative documents and scientific and literary sources that summarize the experience of digital transformation of the European education system and demonstrate how innovation and digitalization contribute to quality vocational education in the new environment. The result of this stage of the study was the awareness of the need for systemic strategic decisions and a clear sequence of steps towards ensuring digital transformation, in particular the development of digital competencies.

2. The review of regulations aimed at ensuring the digital transformation of the domestic economy, education, allowed to see both the main problem (lack of a systemic vision) and o state the positive dynamics in the direction of digital development of education, including vocational education in Ukraine.

3. Emphasis is placed on close cooperation between the European Education Foundation, the Joint Research Center of the European Commission with the Ministry of Education and Science of Ukraine and the Ministry of Digital Transformation of Ukraine in the implementation of joint projects, aimed at determining the level of digital development of educational institutions, the level of digital competence of teachers and students, improving the digital infrastructure. These vectors of digital development, aimed at activating the internal resources of vocational education institutions, have shown the greatest effectiveness both according to European colleagues and in the framework of further experimental testing in the particular vocational (technical) education institution.

4. Specific steps, examples of measures that can ensure the effectiveness and results of digital transformations of educational and management processes within the powers of the administration and methodological service of the institution of vocational (technical) education were considered.

At this stage of the study, preliminary results have been obtained that can be used to form a model of digital transformation of vocational education institutions. It is 
also necessary to take into account the limitation of the positive influence of the identified factors within one educational institution and the need to verify this experi- ence by implementing the activities of methodological services of other institutions of vocational (technical) education.

\section{References}

1. What 800 executives envision for the postpandemic workforce (2020). McKinsey Global Institute. Available at: https://mck.co/3xZAssc Last accessed: 25.05.2021

2. Pohliad kerivnykiv biznesu v Ukraini 2020 | Cpetsvypusk: COVID-19 (2020). Doslidzhennia KPMG v Ukraini. Available at: https://bit.ly/3haZUF3 Last accessed: 25.05.2021

3. 2030 Digital Compass: the European way for the Digital Decade (2021). Available at: https://bit.ly/2SvIqsA Last accessed: 25.05.2021

4. Council Resolution on a strategic framework for European cooperation in education and training towards the European Education Area and beyond (2021-2030) (2021). Available at: https://bit.ly/3bgY5m5 Last accessed: 25.05.2021

5. COUNCIL RECOMMENDATION of 24 November 2020 on vocational education and training (VET) for sustainable competitiveness, social fairness and resilience (2020). Available at: http://bit.ly/2NrMhVG Last accessed: 25.05.2021

6. Innovation \& digitalisation A report of the ET 2020 Working Group on Vocational Education and Training (VET): EIGHT insights for pioneering new approaches (2020). Available at: https://bit.ly/2NzRpXF Last accessed: 25.05.2021

7. Council conclusions on digital education in Europe's knowledge societies (2020). Available at: https://bit.ly/3o4Gd39 Last accessed: 25.05 .2021

8. Communication from the commission to the european parliament, the council, the european economic and social committee and the committee of the regions (2020). Achieving the European Education Area by 2025 - Communication. Available at: https://bit.ly/3f81Hud Last accessed: 25.05.2021

9. Communication from the commission to the european parliament, the council, the european economic and social committee and the committee of the regions. Digital Education Action Plan 2021-2027 Resetting education and training for the digital age (2020). Available at: https://bit.ly/3eZHRic Last accessed: 25.05.2021

10. Manifesto for enhancing digital competences across Europe (2021). Available at: https://all-digital.org/digitalcompetences-manifesto-text/ Last accessed: 25.05.2021

11. Koriavets, M. A. (Ed.) (2021). Kerivnytstvo dlia rozrobky Natsionalnoi stratehii rozvytku tsyfrovykh navychok i kompetentnostei v Ukraini vidpovidno do yevropeiskoho dosvidu. Analitychnyi dokument, 74. Available at: https://bit.ly/3oeUjiF Last accessed: 25.05.2021

12. Proiekt Kontseptsii tsyfrovoi transformatsii osvity i nauky na period do 2026 roku (2021). Available at: http://ndch.diit.edu.ua/ua/news/transformation2026.html Last accessed: 25.05.2021

13. Nanaieva, T. (2021). Selfie hackathon in ukraine: could selfie and a hackathon match? Open Space. Available at: https://openspace.etf.europa.eu/blog-posts/selfie-hackathon-ukraine-could-selfie-and-hackathon-match Last accessed: 26.06 .2021 25.05.2021

14. Opys ramky tsyfrovoi kompetentnosti dlia hromadian Ukrainy (2021). Available at: https://bit.ly/3rBs8KL Last accessed: 26.06.2021

15. The digital competence wheel. Koleso tsyfrovoi transformatsii. Available at: https://digital-competence.eu Last accessed:

16. MyDigiSkills. Available at: https://mydigiskills.eu/ua/ Last accessed: 26.06 .2021

17. Zrazok nakazu po zakladu osvity ta Polozhennia pro konkurs-ohliad na krashchyi kurs dystantsiinoho navchannia (2021). Available at: https://drive.google.com/file/d/1xsI1DF7JaMO9CDyz19pMVenflUTqgUtS/view Last accessed: 26.06.2021

18. Elektronnyi zhurnal ta shchodennyk. Atoms (2021). Available at: https://atoms.ua/ Available at: 26.06.2021 26.06.2021

9. Dystantsiina platforma DNZ ZVPU (2021). Available at: https://remoteplatformzvpu.blogspot.com/ Last accessed:

Received date 04.05.2021

Accepted date 15.06.2021

Published date 30.07.2021

Olena Kulynych, Postgraduate Student, Institute of Vocational Education of National Academy of Pedagogical Sciences of Ukraine, Vito-lytovskyi lane, 98a, Kyiv, Ukraine, 03045, Deputy Director for Educational and Methodological Work, State Educational Institution "Zaporizhzhya Higher Vocational School", Zavodska str., 9, Zaporizhia, Ukraine, 69035

E-mail: elankul@ukr.net 